\title{
KINERJA APARATUR PEMERINTAH DESA
}

\author{
Gradila Apriani \\ Fakultas Ilmu Sosial dan Ilmu Politik Universitas Kapuas Sintang \\ Jln. Y.C. Oevang Oeray No. 92 Sintang, Kalimantan Barat \\ Email: gradilaapriani@gmail.com
}

\begin{abstract}
Abstrak : Penyelenggaraan Pemerintahan Desa merupakan subsistem dari sistem penyelenggaraan pemerintahan nasional. Oleh sebab itu aparatur pemerintah desa diharapkan memiliki kinerja yang maksimal demi tercapainya suatu pemerintahan yang baik. Tujuan penelitian ini bertujuan untuk mengetahui kinerja aparatur pemerintah desa dalam penyelenggaraan pemerintahan. Fokus penelitian ini yaitu kinerja aparatur desa yang penulis rumuskan dalam ruang lingkup penelitian dengan indikator teori yaitu tanggung jawab, keterampilan dan pemahaman dalam bidang kerja.
\end{abstract}

Kata Kunci : Kinerja, Aparatur, Pemerintah Desa.

Pembangunan pada hakekatnya merupakan upaya yang dilakukan oleh masyarakat untuk memperbaiki keterbelakangan dan ketertinggalan dalam semua bidang kehidupan, guna menuju suatu keadaan yang lebih baik dari keadaan sebelumnya, dilakukan dengan rangkaian upaya pembangunan berkesinambungan, yang dilaksanakan bersama oleh masyarakat dan pemerintah menuju terwujudkan masyarakat adil dan makmur. Masyarakat adalah pelaku utama pembangunan dan pemerintah berkewajibanuntuk mengarahkan, membimbing serta menciptakan suasana yang menunjang. Undang-Undang Republik Indonesia Nomor 6 Tahun 2014 Tentang Desa, dimana menempatkan Desa untuk memiliki otonominya sendiri dan telah membentuk tatanan desa sebagai masyarakat self-governing community dengan local-self goverment. Sebuah tatanan kehidupan masyarakat yang diharapkan mampu mengakomodasi kesatuan dan persatuan masyarakat hukum adat sebagai konstruksi kebhinekaan Negara Kesatuan Republik Indonesia. Keberhasilan pembangunan Kabupaten/ kotakhususnya dalam konsep otonomi daerah, dimana Aparatur Pemerintahan Desa akan terlibat langsung dalam perencanaan pembangunan dan pelayanan publik.

Pemerintahan Desa merupakan organisasi dalam penyelenggaraan pemerintah yang terdepan dalam berhubungan langsungkepada masyarakat di desa, tentunya berkewajibanuntuk mengimplementasikan program-program. Pemerintahan Desa berfungsi sebagai pengayom, pembina, pelayan, dan penggerak partisipasi masyarakat yang berdasarkan pada asas kepastian hukum, tertib penyelenggaran pemerintahan, tertib kepentingan umum, profesionalitas, akuntabilitas, efektivitas dan efisiensi, serta partisipatif. Hal ini, mengisyaratkan dimana dalam memberikan pelayanan kepada masyarakat, Aparatur Pemerintah Desa dituntut bekerja dengan kemampuan optimal guna memperlancar pelaksanaan tugas pemerintahan. Pelaksanaan dari tugas pokok dan fungsi AparaturPemerintah Desa semakin menjadi sorotan masyarakat, karena untuk mendapatkan pelayanan yang baikadalah hak masyarakat, sedangkan aparatur berkewajiban menyelenggarakan pelayanan secaraprima, dengan prinsip-prinsip pelayanan yang sederhana, cepat, tepat, tertib, murah, transparandan tidak diskriminatif.Masyarakat tidak hanya menuntut pelayanan publik yang lebih efisien,dan memuaskan, tetapijuga menginginkan perilaku administrasi publik yang lebih responsivedan mencerminkan kepatutan (fairness), keseimbangan etika dan kearifan.Tuntutan yang gencardilakukan oleh masyarakat kepada pemerintah merupakan tuntutan yang wajar yang sudahseharusnya direspon oleh pemerintah dengan melakukan perubahan-perubahan yang terarah dengan terwujudnya penyelenggaraan Pemerintah Desa yang baik.

Pencapaian tujuan setiap organisasi pemerintahan didukung oleh kinerja dari setiap aparaturnya. Kinerja yang tinggi timbul apabila seseorang bersikap dan memandang kerja sebagai sesuatu hal yang luhur untuk eksistensi manusia.Hal ini dijadikan sebagai suatu kesempatan untuk mengembangkan diri dan berbuat sesuatu untuk masyarakat. Masalah dari minimnya sumber daya aparatur masih menjadi sorotan dan tumpuhan bagi setiap instansi pemerintahan untuk tetap dapat bertahan di era globalisasi. sumber daya aparatur mempunyai peran utama dalam setiap kegiatan organisasi pemerintahan. Walaupun didukung dengan sarana dan prasarana serta sumber dana yang berlimpah, tetapi tanpa dukungan sumber daya aparatur yang andal kegiatan organisasi 
pemerintahan tidak akan terselesaikan dengan baik. Hal ini menunjukkan bahwa sumber daya aparatur merupakan kunci pokok yang harus diperhatikan dengan segala kebutuhannya.

Menurut Filippo (2011:31) Akuntabilitas merupakan istilah yang digunakan untuk menggambarkan tingkat pertanggungjawaban seseorang ataupun suatu lembaga tertentu yang berkaitan dengan sistem administrasi yang dimilikinya. Indikator tanggung jawab dapat diukur dari; 1). tugas yang dibebankan; 2). usaha untuk memajukan insitusi". Akuntabilitas merupakan salah satu pilar good government yang merupakan pertanggung jawaban pemerintah dalam mengambil suatu keputusan untuk kepentingan publik, dalam hal ini sebagaimana pertanggung jawaban pemerintah terhadap pelayanan publik yang diberikan. Menurut Mardiasmo (2002:20) Pengertian akuntabilitas publik adalah "kewajiban pihak pemegang amanah untuk memberikan pertanggung jawaban, menyajikan, melaporkan dan mengungkapkan segala aktivitas kegiatan yang menjadi tanggung jawabnya kepada pihak pemberi amanah yang memiliki hak dan kewenangan untuk meminta pertanggungjawaban tersebut."

Menurut Hasibuan (2007:35) pemerintah yang accountable memiliki ciri-ciri Mampu menyajikan informasi penyelenggaraan pemerintah secara terbuka, cepat, dan tepat kepada masyarakat. Mampu memberikan pelayanan yang memuaskan bagi publik. Mampu memberikan ruang bagi masyarakat untuk terlibat dalam proses pembangunan dan pemerintah. Mampu menjelaskan dan mempertanggung jawabkan setiap kebijakan publik secara proporsional, dan Adanya sarana bagi publik untuk menilai kinerja pemerintah. Melalui pertanggung jawaban publik, masyarakat dapat menilai derajat pencapaian pelaksanaan program dan kegiatan pemerintah. UndangUndang Republik Indonesia Nomor 6 Tahun 2014 Tentang Desa, yang dimaksud dengan Pemerintahan Desa adalah Penyelenggaraan urusan pemerintahan dan kepentingan masyarakat setempat dalam sistem pemerintahan Negara Kesatuan Republik Indonesia, yang berdasarkan asas : Kepastian Hukum; Tertib Penyelenggaraan Pemerintahan; Tertib Kepentingan Umum; Keterbukaan; Proporsionalitas; Profesionalitas; Akuntabilitas; Efektivitas dan Efisiensi; Kearifan Lokal; Keberagaman; Partisipatif “. Menurut Mardiasmo (2002:21) Akuntabilitas terdiri dari dua macam, adapun penjelasan dari jenis-jenis akuntabilitas adalah Akuntabilitas vertikal (internal). Setiap pejabat atau petugas publik baik individu maupun kelompok secara hierarki berkewajiban untuk mempertanggungjawabkan kepada atasan langsungnya mengenai perkembangan kinerja atau hasil pelaksanaan kegiatan secara periodik maupun sewaktu-waktu bila diperlukan. Akuntabilitas Horizontal (eksternal). Akuntabilitas horizontal (eksternal) melekat pada setiap lembaga negara sebagai suatu organisasi untuk mempertanggung jawabkan semua amanat yang telah diterima dan dilaksanakan ataupun perkembangannya untuk dikomunikasikan kepada pihak ekternal (masyarakat luas) dan lingkungannya (public or external accountability and environment).

Dalam Undang-Undang Republik Indonesia Nomor 6 Tahun 2014 tentang Desa pada pasal 67 menyebutkan bahwa hak dan kewajiban desa adalah Desa berhak : Mengatur dan mengurus kepentingan masyarakat berdasarkan hak asal usul, adat istiadat, dan nilai sosial budaya masyarakat Desa. Menetapkan dan mengelola kelembagaan Desa; dan Mendapatkan sumber pendapatan. Desa berkewajiban : Melindungi dan menjaga persatuan, kesatuan, serta kerukunan masyarakat Desa dalam rangka kerukunan nasional dan keutuhan Negara Kesatuan Republik Indonesia. Meningkatkan kualitas kehidupan masyarakat Desa. Mengembangkan kehidupan demokrasi. Mengembangkan pemberdayaan masyarakat Desa. Memberikan dan meningkatkan pelayanan kepada masyarakat Desa.

Menurut Undang-Undang Republik Indonesia Nomor 6 Tahun 2014 tentang Desa pada pasal 68 menyebutkan bahwa hak dan kewajiban masyarakat desa adalah Masyarakat Desa berhak: Meminta dan mendapatkan informasi dari Pemerintah Desa serta mengawasi kegiatan penyelenggaraan Pemerintahan Desa, pelaksanaan Pembangunan Desa, pembinaan kemasyarakatan Desa, dan pemberdayaan masyarakat Desa. Memperoleh pelayanan yang sama dan adil. Menyampaikan aspirasi, saran, dan pendapat lisan atau tertulis secara bertanggung jawab tentang kegiatan penyelenggaraan Pemerintahan Desa, pelaksanaan Pembangunan Desa, pembinaan kemasyarakatan Desa, dan pemberdayaan masyarakat Desa. Memilih, dipilih, dan/atau ditetapkan menjadi: Kepala Desa, Perangkat Desa, Anggota Badan Permusyawaratan Desa, Anggota lembaga kemasyarakatan Desa. Mendapatkan pengayoman dan perlindungan dari gangguan ketenteraman dan ketertiban di Desa. Masyarakat Desa berkewajiban : Membangun diri dan memelihara lingkungan desa. Mendorong terciptanya kegiatan penyelenggaraan Pemerintahan Desa, pelaksanaan pembangunan desa, pembinaan kemasyarakatan desa, dan pemberdayaan masyarakat desa yang baik. Mendorong terciptanya situasi yang aman, nyaman, dan tenteram di desa. Memelihara dan mengembangkan nilai permusyawaratan, permufakatan, kekeluargaan, dan kegotongroyongan di desa. Berpartisipasi dalam berbagai kegiatan di desa. Menurut Sudarmanto (2009:60) "Keterampilan adalah perilaku yang terkait dengan tugas, yang bisa dikuasai melalui pembelajaran, dan 
bisa ditingkatkan melalui pelatihan dan batuan orang lain. Keterampilan merujuk pada kemampuan seseorang untuk melakukan suatu kegiatan. Adapun perilaku adalah manifestasi kepribadian dan sikap yang ditunjukkan ketika seseorang berinteraksi dengan lingkungannya".

Menurut Suwatno (2008:23) Keterampilan merupakan domain yang sangat penting untuk meningkatkan kinerja pegawai. Keterampilan yang lebih baikakan terus dapat meningkatkan kinerja pegawai, berikut adalah ciri-ciri pegawai yang telah memiliki keterampilan dengan baik: Tahu dan mengerti apa yang harus dikerjakan. Mempunyai gerak kerja yang cepat dan tepat. Jarang sekali melakukan kesalahan dan kekeliruan dalam bekerja. Sudah mempunyai kiat-kiat tertentu dalam melaksanakan pekerjaan. Produktivitas kerja meningkat dari biasanya. Menurut Soehardi (2003:24) "kemampuan (abilities) seseorang akan turut serta menentukan perilaku dan hasilnya. Maksud dari kemampuan atau abilities ialah bakat yang melekat pada seseorang untuk melakukan sesuatu kegiatan secara fisik atau mental yang ia peroleh sejak lahir, belajar, dan dari pengalaman". Menurut Robbins (2006:22) "Kemampuan (ability) adalah kapasitas individu untuk melaksanakan berbagai tugas dalam pekerjaan tertentu. Seluruh kemampuan seorang individu pada hakekatnya tersusun dari dua perangkat faktor yaitu : Kemampuan intelektual adalah kemampuan yang diperlukan untuk menjalankan kegiatan mental. Kemampuan fisik adalah kemampuan yang diperlukan untuk melaksanakan tugas-tugas yang menuntut stamina, kecekatan, kekuatan dan keterampilan serupa".

Menurut Moenir (2008:15) menjelaskan ada beberapa Kemampuan yang diperlukan dalam suatu instansi agar pegawai dapat mengerjakan tugas yang dibebankan padanya. beberapa kemampuan yang harus dimiliki oleh pegawai untuk mencapai efektifitas dan efisiensi kerja, yaitu: Kemampuan Teknis (Technical Skill) Adalah pengetahuan dan penguasaan kegiatan yang bersangkutan dengan cara proses dan prosedur yang menyangkut pekerjaan dan alat-alat kerja. kemampuan teknis yang dimaksud seseorang pegawai di dalam perusahaannya harus mampu dalam penguasaan terhadap metode kerja yang ada atau yang telah ditugaskan. Kemampuan Bersifat Manusiawi(Human Skill) Adalah kemampuan untuk bekerja dalam kelompok suasana di mana organisasi merasa aman dan bebas untuk menyampaikan masalah. Kemampuan bersifat manusiawi yang dimaksud kemampuan yang dimiliki oleh karyawan dalam bekerja, bisa kelompok kerja ataupun tim kerja yakni bekerja sama dengan sesama anggota kerjanya. Hal ini penting sekali karena kemampuan dalam berkomunikasi dapat mengeluarkan ide yang bagus, pendapat bahkan di dalam penerimaan pendapat maupun saran dari orang lain dapat menjadi faktor keberhasilan melaksanakan tugas yang baik. Kemampuan Konseptual (Conceptual Skill)Adalah kemampuan untuk melihat gambar kasar untuk mengenal adanya unsur penting dalam situasi memahami di antara unsur-unsur itu. kemampuan konseptual yang dimaksud kemampuan bagi seorang karyawan apabila sebagai (decision maker) ataupengambil keputusan dalam menganalisis dan merumuskan tugas-tugas yang di embannya. Dengan kemampuan ini maka pekerjaan dapat berjalan dengan baik karena dapat memilih prioritas-prioritas pekerjaan mana yang harus didahulukan.

Menurut Hasibuan (2012:31) indikator kemampuan kerja diantaranya Pengetahuan (knowledge). Pengetahuan merupakan fondasi yang mana akan membangun keterampilan dan kemampuan. Pengetahuan terorganisasi dari informasi, fakta, prinsip atau prosedur yang jika diterapkan membuat kinerja yang memadai dari pekerjaan. Pelatihan (training). Proses pendidikan jangka pendek yang menggunakan prosedur sistematis dan terorganisir sehingga tenaga kerja non-manajerial mempelajari pengetahuan dan keterampilan teknis untuk tujuan tertentu. Pengalaman (experience). Tingkat penguasaan pengetahuan serta keterampilan seseorang dalam pekerjaannya yang dapat diukur dari masa kerja dan tingkat pengetahuan serta keterampilan yang dimiliki. Keterampilan (skill). Kemampuan seseorang dalam menguasai pekerjaan, penguasaaan alat dan menggunakan mesin tanpa kesulitan. Kesanggupan Kerja, Kondisi dimana seorang karyawan merasa mampu menyelesaikan pekerjaan yang diberikan.

Menurut Robbins (2006:35) menjelaskan bahwa "tingkat kinerja pegawai akan sangat tergantung pada faktor kemampuan pegawai itu sendiri seperti tingkat pendidikan, pengetahuan, pengalaman dimana dengan tingkat kemampuan yang semakin tinggi akan mempunyai kinerja semakin tinggi pula. Dengan demikian tingkat pendidikan, pengetahuan dan pengalaman yang rendah akan berdampak negatif pada kinerja pegawai". Menurut Wibowo (2007:102) mengungkapkan bahwa terdapat beberapa faktor yang dapat mempengaruhi kemampuan seseorang pegawai, yaitu Keyakinan dan Nilai-nilai, Keterampilan, Pengalaman, Karakteristik kepribadian, Motivasi, Isu emosional. Dalam Penyelenggaraan Pemerintah Desa, pemahaman dalam bidang kerja adalah sesuatu yang harus dimiliki setiap aparatur Pemerintah Desa baik Kepala Desa, maupun Perangkat Desa, hal tersebut tidak lepas dari peran Aparatur Pemerintah Desa sebagai ujung tobak pembangunan. Menurut Sudaryono (2012:44) "pemahaman adalah kemampuan seseorang untuk menangkap makna dan arti dari bahan yang dipelajari, yang dinyatakan 
dengan menguraikan isi pokok dari suatu bacaan atau mengubah data yang disajikan dalam bentuk tertentu ke bentuk yang lain". Menurut Sudijono (2009:50) "pemahaman (Comprehension) adalah kemampuan seseorang untuk mengerti atau memahami sesuatu setelah sesuatu itu diketahui dan diingat. Dengan kata lain, memahami adalah mengerti tentang sesuatu dan dapat melihatnya dari berbagai segi".

Menurut Wibowo (2007:104) pemahaman seorang aparatur desa dapat diukur melalui tiga indikator, yaitu : Tingkat pendidikan formal yang dimiliki, Pelatihan Teknis yang pernah diikuti, Penguasaan secara mendalam pekerjaan tersebut. Menurut Nurcholis (2011:138) menjelaskan bahwa Pemerintah desa adalah unsur penyelenggaraan pemerintah mempunyai tugas pokok: Melaksanakan urusan rumah tangga desa, urusan pemerintahan umum, membangun dan membina masyarakat. Menjalankan tugas pembantuan dari pemerintah, pemerintah provinsi dan pemerintah kabupaten. Menurut Rivai (2004:53) fungsi pemerintah desa merupakan gejala sosial, karena harus diwujudkan dalam interaksi antar individu didalam situasi sosial suatu kelompok masyarakat. Adapun fungsi pemerintah desasecara operasional dapat dibedakan dalam fungsi pokok, yaitu sebagai berikut: Fungsi Instruktif, Fungsi ini bersifat komunikasi satu arah. Pemerintah sebagai komunikator merupakan pihak yang menentukan apa, bagaimana, bilamana, dan dimana pemerintah itu dikerjakan agar keputusan dapat dilaksanakan secara efektif. Fungsi Konsultatif, Fungsi ini digunakan sebagai komunikasi dua arah. Hal tersebut digunakan sebagai usaha untuk menetapkan keputusan yang memerlukan bahan pertimbangan dan mungkin perlu konsultasi dengan masayarakat-masyarakat yang di pimpinnya. Fungsi Partisipasi, Dalam menjalankan fungsi ini pemerintah desa berusaha mengaktifkan masyarakatnya, baik dalam keikutsertaan mengambil keputusan maupun dalam melaksanakannya. Partisipasi tidak berarti bebas berbuat semaunya, tetapi dilakukan secara terkendali dan terarah berupa kerjasama dengan tidak mencampuri atau mengambil tugas pokok orang lain. Fungsi Delegasi, Fungsi ini dilaksanakan dengan memberikan pelimpahan wewenang membuat atau menetapkan baik melalui persetujuan maupun tanpa persetujuan pemerintah. Fungsi delegasi ini pada dasarnya berarti kepercayaan. Fungsi Pengendalian, Fungsi pengendalian berasumsi bahwa kepemimpinan yang efektif harus mampu mengantar aktivitas anggotanya secara terarah dan dalam. Koordinasi yang efektif, sehingga memungkinkan tercapainya tujuan bersama secara maksimal dalam melaksanakan fungsi pengendalian pemimpin dapat mewujudkannya melalui kegiatan bimbingan, pengarahan, koordinasi dan pengawasan.
Menurut Agus Fitriyanto (2006 :11) mengemukakan bahwa "Pemahaman kerja adalah kondisi yang menunjukkan adanya keserasian antara kematangan fisik, mental serta pengalaman sehingga individu mempunyai kemampuan untuk melaksanakan suatu kegiatan tertentu dalam hubungannya dengan pekerjaan". Selanjutnya Mathis dan Jackson (2006:214) menyatakan ada tiga hal yang menjadi ukuran deskripsi kerja yang perlu diperhatikan yaitu: Tugas dan tanggung jawab esensial. Pengetahuan, keterampilan dan kemampuan yang dibutuhkan, dan Kerjasama yang dilakukan dalam menjalankan tugas yang didelegasikan. Menurut Sedermayanti (2010:55) pemahaman mengenai profesionalisme pegawai atau tenaga kerja. Ia mengemukakan bahwa tenaga kerja pada hakikatnya mengandung aspek-aspek: Aspek Potensial, bahwa setiap tenaga kerja memiliki potensi-potensi yangbersifat dinamis, yang terus berkembang dan dapat dikembangkan.Potensi-potensi itu antara lain: daya mengingat, daya berpikir, dayaberkehendak, daya perasaan, bakat, minat, motivasi, dan potensipotensilainnya. Aspek Profesionalisme dan vokasional, bahwa setiap tenaga kerjamemiliki kemampuan dan keterampilan kerja atau kejujuran dalam bidangtertentu, dengan kemampuan dan keterampilan itu, dia dapat mengabdikandirinya dalam lapangan kerja tertentu dan menciptakan hasil yang baiksecara optimal. Aspek Fungsional, bahwa setiap tenaga kerja melaksanakan pekerjaannyasecara tepat guna, artinya dia bekerja sesuia dengan tugas dan fungsinyadalam bidang yang sesuai pula, misalnya seorang tenaga kerja yangmemiliki keterampilan dalam bidang elektronik. Aspek Operasional, bahwa setiap tenaga kerja dapat mendayagunakankemampuan dan keterampilanya dalam proses dan prosedur pelaksanaankegiatan kerja yang sedang ditekuninya. Aspek Personal, bahwa setiap kerja harus memilki sifat-sifat kebribadianyang menunjang pekerjaannya, misalnya: sikap mandiri dan tangguh, bertanggung jawab, tekun dan rajin. Aspek Produktivitas, bahwa setiap tenaga kerja harus memilki motifberprestasi, berupaya agar berhasil dan memberikan hasil daripekarjaannya, baik kuantitas maupun kualitas.

Menurut Sudjana (1992: 24) bahwa Pemahaman dapat dibedakan kedalam 3 kategori, yaitu: Tingkat terendah adalah pemahaman terjemahan, mulai dari menerjemahkan dalam arti yang sebenarnya, mengartikan dan menerapkan prinsip-prinsip, Tingkat kedua adalah pemahaman penafsiran yaitu menghubungkan bagian-bagian terendah dengan yang diketahui berikutnya atau menghubungkan beberapa bagian grafik dengan kejadian, membedakan yang pokok dengan yang tidak pokok dan Tingkat ketiga merupakan tingkat pemaknaan ektrapolasi. Memiliki pemahaman tingkat ektrapolasi berarti seseorang mampu 
melihat dibalik yang tertulis, dapat membuat estimasi, prediksi berdasarkan pada pengertian dan kondisi yang diterangkan dalam ide-ide atau simbol, serta kemampuan untuk membuat kesimpulan yang dihubungkan dengan implikasi dan konsekuensinya.

\section{METODE}

Jenis penelitian ini adalah penelitian deskriptif. Menurut Moleong (2014:6) mengemukakan bahwa "penelitian deskriptif adalah prosedur pemecahan masalah yang diselidiki, menggambarkan atau menjelaskan keadaan objek penelitian pada saat sekarang, berdasarkan faktafakta yang tampak atau sebagaimana mestinya. Dalam penelitian diskriptif ini, sifatnya menggali, menyusuri, menentukan fakta-fakta, masalah atau kendala yang mungkin dihadapi sekaligus memberikan penjelasan. Sedangkan metode kualitatif sendiri adalah suatu konsep keseluruhan untuk mengungkapkan rahasia sesuatu yang dilakukan dengan menghimpun data dalam keadaan sewajarnya, dengan menggunakan cara kerja yang sistematik, terarah dan dapat dipertanggung jawabkan untuk memecahkan suatu masalah dengan cara memaparkan, menafsirkan, menganalisa, serta menginterpretasikan data yang ada". Dalam penelitian ini peneliti menemui Kepala Desa, Sekretaris Desa, Kepala Urusan (Kaur) Umum dan Keuangan, Kepala Urusan (Kaur) Pemerintah, Kepala Urusan (Kaur) Pembangunan, Bendahara Desa dan Ketua Badan Permusyawaratan Desa (BPD). Pengumpulan data dilakukan di Desa Bancoh dengan melakukan observasi, wawancara dan studi dokumentasi. Hasil penelitian dianalisis menggunakan analisis kualitatif.

\section{HASIL PENELITIAN DAN PEMBAHASAN}

Kinerja adalah hasil kerja secara kualitas dan kuantitias yang dicapai oleh seorang aparatur dalam melaksanakan tugasnya sesuai dengan tanggung jawab yang diberikan kepadanya. Dalam melakukan suatu pekerjaan, seorang aparatur hendaknya memiliki kinerja yang tinggi. Kinerja aparatur yang rendah akan menjadi suatu permasalahan bagi sebuah organisasi atau lembaga, karena kinerja yang dihasilkan aparatur tidak sesuai dengan yang diharapkan oleh organisasi. Aparatur Pemerintah Desa Bancoh sebagai pihak yang memegang amanah untuk mengelola dan melaksanakan penyelenggaraan pemerintahan demi melayani seluruh masyarakat yang berkewajiban dalam menjalankan setiap tugasnya sebagai bentuk tanggungjawab terhadap amanah yang dipegangnya. Tanggung jawab dalam hal ini adalah kesediaan atau kemampuan aparatur dalam menyelesaikan pekerjaan yang diberikan kepadanya dengan sebaik-baiknya dan tepat pada waktunya, serta berani menerima resiko atas pekerjaan yang dilakukan.
Kepala Desa yang merupakan orang yang bertanggung jawab penuh terhadap penyelenggaraan pemerintah desa, merupakan satu kesatuan dengan pengelolaan keuangan desa yakni keseluruhan kegiatan yang meliputi perencanaan, penganggaran, penatausahaan, pelaporan, pertanggungjawaban dan pengawasan keuangan desa. Selaku penanggung jawab dari setiap kegiatan penyelenggaraan pemerintah desa, maka selalu mengkoordinasikan dengan perangkat aparatur pemerintah desa dalam setiap menjalankan tugas-tugasnya dan melaksanakan kegiatan-kegiatan yang telah direncanakan dan disetujui. Dalam penyelenggaraan pemerintahan, dimana pemerintah desa bertanggung jawab melakukan pekerjaan sesuai dengan tugas dan fungsi yang sudah dipercayakan kepada masingmasing bagian dalam unsur pemerintahan desa yang dibebankan sebagai wujud tanggung jawab untuk melaksanakan tugas, fungsi dan wewenang yang telah dipercayakan kepada setiap aparatur pemerintahan desa dalam menyelenggaraan pemerintahan desa. Sekretaris Desa menjelaskan bahwa bentuk akuntabilitas dan transparansi pemerintah desa dalam mempertanggungjawabkan laporan pengelolaan APBDes dengan cara memberikan laporan kepada masyarakat yaitu dengan menempelkan laporan pengelolaan APBDes dipapan pengumuman pembangunan yang telah disediakan di balai desa. Selain itu pemerintah desa juga menyampaikan laporan realisasi pengelolaan APBDes kepada BPD, dan Lembaga Permberdayaan Masyarakat (LPM) pada saat musyawarah penyusunan dan pelaporan APBDes. Dalam melakukan pengelolaan keuangan APBDes tentunya ada pengawasan, semua pemerintah desa telah diawasi oleh tim Badan Pengelola Keuangan dan Pembangunan (BPKP). Selain itu diawasi oleh BPD dan masyarakat, tim ferivikasi dari Kecamatan, Inspektorat, dan juga Bapenas.

Tanggung jawab dalam pengelolaan keuangan desa dilaksanakan oleh tim pengelola keuangan. Tim pengelolaan tersebut antara lain Kepala Desa selaku pemegang kekuasaan pengelolaan keuangan desa dan mewakili pemerintah desa dalam kepemilikan kekayaan desa yang dipisahkan. Selanjutnya Kepala Desa dibantu oleh tim Pelaksanaan Teknis Keuangan Desa (PTKD) yang terdiri dari Sekdes, Kaur Umum dan Keuangan, serta Bendahara Desa. Dimana tupoksi dari tim PKTD yaitu Sekdes bertugas untuk meyusun semua bukti tertulis atas pengelolaan keuangan desa, Kaur Umum dan Keuangan bertugas sebagai pelaksanaan kegiatan sesuai bidangnya, sedangkan Bendahara Desa mempunyai tugas dan fungsi sebagai penerima, menyimpan, menyetorkan, membayar, menata usahakan, dan bertanggungjawab penerimaan 
pendapatan desa dan pengeluaran pendapatan desa dalam rangka pelaksanaan APBDes.

Aparatur Desa bertanggung jawab membantu Kepala Desa dalam melaksanakan pengelolaan administrasi kependudukan, administrasi pertanahan, pembinaan, ketentraman dan ketertiban masyarakat desa, serta juga mempersiapkan bahan perumusan kebijakan penataan kebijakan dalam penyusunan produk hukum desa. Selain itu bertanggung jawab pula membantu Kepala Desa dalam melaksanakan penyiapan bahan perumusan kebijakan teknis pembangunan desa dan potensi desa, pengelolaan administrasi pembangunan, pengelolaan pelayanan masyarakat serta penyiapan bahan usulan kegiatan dan pelaksanaan tugas pembantuan. Dimana tanggung jawab pembangunan fisik yang telah dilaksanakan di Desa Bancoh tidak belum sepenuhnya terlaksana dengan maksimal, walaupun sebelum pelaksanaan pembangunan dilakukan persiapan-persiapan seperti halnya diadakan musyawarah berkaitan dengan masalah pendanaan, namun sampai pada pelaksanaan dana tersebut sering tidak mencukupi atau tidak sesuai dengan rencana pembangunan yang harus tercapai dan biasanya pemerintah desa hanya melaksanakan secukupnya saja, namun kadang kemudian masyarakat akhirnya swadaya dengan menarik iuran untuk menyelesaikan pembangunan tersebut. Transparansi dan akuntabiliats pengelolaan APBDes di Desa Bancoh Kecamatan Sungai Tebelian Kabupaten Sintang sudah berdasarkan pada prinsip transparansi, dan bisa dipertanggungjawabkan.Penyelesaian pekerjaan dengan baik dan tepat waktu merupakan tolak ukur keberhasilan dalam mencapai pekerjaan yang baik. Hasil pekerjaan adalah ukuran kemampuan, ketelitian serta tanggung jawab.

Keterampilan adalah penguasaan terhadap berbagai teknik, prosedur serta peraturan yang berhubungan dengan bidang tugas yang dimiliki oleh aparatur desa. Terkait penelitian ini, Penulis fokus pada keterampilan teknik, dan keterampilan administratif. Rata-rata Aparatur Desa masih belum menguasai keterampilan teknik, adapun yang dimaksud keterampilan teknik yaitu kemampuan untuk menggunakan peralatan-peralatan, prosedurprosedur atau teknik dari suatu bidang tertentu erat kaitannya dengan penggunaan fasilitas-fasilitas atau alat-alat elektronik seperti komputer, printer, faxmail, wifi dan lain-lain. Keterampilan teknik khususnya dalam pengoperasian IT atau komputer memang rata-rata aparatur desa belum mampu untuk melaksanakannya secara maksimal, untuk itu Kepala Desa sudah berusaha untuk meningkatkan kemampuan tersebut dengan mengikutsertakan seluruh aparatur dalam pelatihan komputer.
Selanjutnya selain keterampilan teknik yang harus dikuasai, Aparatur Desa juga harus mengusasi keterampilan administratif agar lebih menunjang pekerjaannya karna keterampilan administratif adalah keterampilan yang dibutuhkan dalam bidang pekerjaan administrasi, seperti misalnya komunikasi, mengorganisasi, merencanakan, atau menyusun skejul. Bagian administrasi bukan hanya dituntut untuk terampil menyelesaikan tugas-tugasnya di kantor, namun juga perlu memiliki sikap positif terhadap pekerjaan. Mereka dituntut untuk bisa merencanakan, mengorganisir serta mengontrol seluruh pekerjaan dengan baik, agar seluruh pekerjaan dapat diselesaikan dengan cepat dan tepat. Maka dari itu, keterampilan Aparatur Desa mengenai manajemen perkantoran, meliputi fungsi administrasi dan pengarsipan sangat diperlukan dalam mengelola kantor sebagai sumber informasi yang efektif. Dalam pelaksanaan tugas dan fungsinya memang belum sepenuhnya memahami dalam pengisian administrasi Keuangan yang mana melaksanakan kegiatan pencatatan data dan informasi mengenai pengelolaan keuangan desa pada buku administrasi keuangan karena kurangnya pelatihan mengenai keterampilan administratif yang dilaksanakan.

Administrasi pemerintahan desa adalah keseluruhan proses kegiatan pencatatan data dan informasi mengenai pemerintahan desa pada buku register desa yang terdiri dariadministrasi umum yaitu pencatatan data dan informasi mengenai kegiatan pemerintahan desa pada buku administrasi umum, administrasi penduduk yaitu kegiatan pencatatan data dan informasi mengenai kependudukan pada buku administrasi penduduk, dan Administrasi Pembangunan adalah kegiatan pencatatan data dan informasi pelaksanaan pembangunan dan pemberdayaan masyarakat pada buku administrasi pembangunan. Peran pemerintahan dalam penyelenggaraan administrasi pemerintahan desa belumlah berjalan secara optimal, karena belum bisa secara mandiri dilaksanakan. Karena keterbatasan keterampilan dalam penyusunan administrasi dalam membantu Sekretaris Desa dalam melaksanakan pengelolaan sumber pendapatan desa, pengelolaan administrasi keuangan desa dan mempersiapkan bahan penyusunan APBDes. Pemerintah Desa Bancoh dalam pembuatan administrasi masih mengandalkan bantuan ahli dari luar pemerintahan desa. Keterbatasan kemampuan sumber daya perangkat desa sangat berpengaruh terutama yang berkaitan dengan lambatnya penyelesaian administrasi. Dalam pengelolaan keuangan desa khususnya pengelolaan dana desa yang terdapat beberapa proses tahapan yaitu mulai dari perencanaan hingga pertanggungjawaban tidak terhindarkan dari penyelesaian urusan administrasi yang dilakukan oleh pemerintah desa. 


\section{KESIMPULAN DAN SARAN}

Keterampilan aparatur pemerintah Desa Bancoh masih perlu ditingkatkan lagi adanya pelatihan agar dapat mempercepat peningkatan keterampilan semua Aparatur Desa karena pencapaian tujuan organisasi juga sangat bergantung pada tingkat kerja sama yang ditunjukkan oleh Aparatur Desa yang didasari dengan keterampilan yang baik. Sumber daya aparatur merupakan faktor utama dalam penyelenggaraan roda pemerintahan di desa. Aparatur pemerintahan merupakan asset yang paling penting, yang harus dimiliki oleh suatu instansi pemerintah untuk menghasilkan kinerja pemerintahan yang baik dan efisien, sesuai dengan bidang kemampuan yang dimiliki oleh setiap aparatur pemerintahan yang melaksanakan tugas dan kewajiban yang diembannya. Kualitas dari Sumber Daya Aparatur Pemerintah Desa Bancoh juga masih tergolong rendah, hal ini terlihat dari segi tingkat pendidikan aparatur sehingga dalam pelayanan masyarakat dan pelaksanaan perannya relatif masihrendah, sehingga masih dibutuhkan arahan dan bimbingan dari pihak-pihak yang dirasa mampu. Hal tersebut disadari sepenuhnya oleh unsur penyelenggara pemerintahan desa sebab karena keterbatasan tersebut dalam pemahamannya terkadang aparatur kurang memahami dalam pelaksanaan program-program yang telah di buat. Pemahaman dalam bidang kerja terutama dalam penyusunan administrasi pemerintahan belum berjalan secara optimal. Karena peranan itu belum bisa secara mandiri dilaksanakan karena masih banyak yang tidak dimengerti dalam administrasi pemerintahan, karena itu administrasi belum berjalan secara optimal, semua tugas tersebut selalu dikomunikasikan kepada Kepala Desa.

\section{DAFTAR PUSTAKA}

Agus, Fitriyanto. 2006. Managemen Sumber Daya Manusia. Jakarta: Dineka Cipta.

Flippo, Edwin B. 2011. Manajemen Personalia. Jakarta : PT. Gelora Askara Pratma.

Maleong, Rexy J. 2014. Metodologi Penelitian Kualitatif. Bandung: Remaja Rosda Karya.

Mathis, R.L. \& J.H. Jackson. 2006. Human Resource Management: Manajemen

Sumber Daya Manusia. Terjemahan. Jakarta : Salemba Empat.

Malayu, Hasibuan, 2007. Manajemen Sumber Daya Manusia, Edisi, Revisi, Jakarta : PT. Bumi Aksara

Mardiasmo, 2002, Otonomi dan Manajemen Keuangan Daerah. Jakarta : Salemba Empat.

Moenir. 2008. Manajemen Pelayanan Umum di Indonesia, Jakarta : PT. Bumi Aksara

Robbins, Stephen P. dan Timothy A. Judge. 2006. Perilaku Organisasi Edisi ke-12. Jakarta : Salemba Empat.

Sedarmayanti. 2010. Sumber Daya Manusia dan ProduktivitasKerja. Bandung : CV. Mandar Maju.

Soehardi, 2003. Esensi Perilaku Organisasional. Jakarta : Bumi Aksara

Suwatno dan Tjutju Yuniarsih. 2008. Manajemen Sumber Daya Manusia. Bandung : Alfabeta.

Sudaryono, dkk. 2012. Pengembangan Instrumen Penelitian. Yogyakarta: Graha Ilmu.

Sudijono. Anas. 2009. Pengantar Analisis Kebijakan Publik. Jakarta : PT. Raja Grafindo Persada

Veithzal Rivai dan Jauvani Sagala. 2004. Manajemen Sumber Daya Manusia untuk

Perusahaan Dari Teori ke Praktik. Jakarta : PT Raja grafindo Persada.

Wibowo. 2007. Manajemen Kinerja. Jakarta : PT.Raja Grafindo Parsada.

Undang-Undang Republik Indonesia Nomor 6 Tahun 2014 tentang Desa 